\title{
Why Small Scale Businesses Failed as a Remedy to unemployment problem in Nigeria
}

\author{
Ishola S. Ademola ${ }^{1}$, Olaleye S.O $(\mathrm{PhD})^{2}$, Ajayi E.Olusuyi ${ }^{3}$ Femi Edun $(\mathrm{PhD})^{4}$ \\ ${ }^{1}$ (Department, Internal Control \& Audit/ National Mirror Newspaper, Lagos, Nigeria) \\ ${ }^{2}$ (Department of Economics, Faculty of Social Sciences / Lagos State University, Nigeria) \\ ${ }^{3}$ (Department of Economics \& Accounting College of Management Sciences / Bells University, Otta, Ogun \\ State, Nigeria) \\ ${ }^{4}$ (Department of Economics, Faculty of Social Sciences / Lagos State University, Nigeria)
}

\begin{abstract}
SME or small scale business is described as the engine for rapid growth due to its numerous benefits such as employment generation and contribution to the GDP. In Nigeria, SMEs defined as any enterprise with a maximum assets of N500 million (\$4.2 million) excluding land and working capital with the number of staff not less than 10 or more than 300 (IFC, 2001). Some 98\% of businesses in Nigeria are small- medium - size enterprise. SMEs are the engines of economic growth worldwide. The impact of SMEs on the economy cannot be underestimated, SMEs generate employment, promote the use of local raw materials that require simple technology, promotes innovation and technology development. Promotes intermediate goods for longer firms and job creation, poverty reduction, wealth creation, income distribution and reduction in income disparities (Аremu 2011)

Sadly, this sector with all the benefits is faced with numerous and endless challenges such as poor management practices, lack of information and knowledge of the market, high cost of over head, infrastructural inadequacy etc.

For the purpose of this study, we summarized the challenges facing SMEs into ten; we do not intend to conclusive say they are limited to ten, but just trying to educate, sensitize and encourage SMEs operators to discover various problems facing businesses.
\end{abstract}

Keywords - Small Scale Business, Unemployment, Economic Growth, Marketing Knowledge gap

\section{INTRODUCTION}

It was September 13, 2008, Dimon, the chief executive of JP Morgan Chase, the America third largest bank, had spent part of the evening at an emergency, all-hands -on -deck meeting at the federal reserve bank of new York with dozen of his rival CEOs .Their assignment was to come up with a plan to save Lehman Brothers, the nation fourth largest investment bank. America is about to witness the dramatic week in history. Like most people on Wall Street, they believe government will intervene and prevent the biggest corporation failure ever. Then Dimon dropped the bombshell, it was his ultimate doomsday. Here is the worst news, he announced. "We need to prepare right now for Lehman Brothers failing". Then he paused. "And for Merrill Lynch Failing". He paused again. "And for AIG failing." Another pause. And for Morgan Stanley failing. And after a final, even longer pause he added: And for Goldman Sachs failing. (From Too Big to Fail).

It was first quarter,2008, Dunlop Nigeria shut down its Nigeria operation just like Michelin the previous year, then Transcorp fell, Cadbury Nigeria was in crisis, then Came the CBN reform that exposed the rot and later death of Oceanic, Intercontinental, Bank Phb and Afribank. Medium and small size companies like HiTV, Leventis stores, Stationery Stores were not left out of the epidemic. Death of business is on the increase and will surely continue.

For the purpose of this write up, our study is limited to small scale businesses (SMEs).

SMEs are usually defined according to individual country, depending on the country level of development. A combination of the following parameter is usually used to define SMEs.

I. Numbers of employees

II. Turnover

III. Capital investment

In Nigeria, SMEs defined as any enterprise with a maximum asset base of \#500 million ( $\$ 4.2$ million) excluding land and working capital with the number of staff not less than 10 or more than 300 (IFC, 2001).

Some $98 \%$ of businesses in Nigeria are small -medium-size enterprise.SME s is the engines of economic growth worldwide. The impact of SMEs on the economy cannot be underestimated, SMEs generate employment, promote the use of local raw materials that require simple technology, promotes innovation and technological development. 
Promotes intermediate goods for larger firms and contributes to the economy's GDP.SME sector is the main driving force behind job creation, poverty reduction, wealth creation, income distribution and reduction in income disparities (Aremu 2011)

Despite the huge impact of SMEs on the economy, the sector still suffers neglect and lack of support from government.

Despite the large market availability and potential for rapid growth, 5 out of every 10 SMEs die within the first 12 months, while only 2 make it beyond 10 years.

Sadly most business mangers and SMEs operators don't seem to know why their businesses fail. This fact was confirmed in 2011 when a survey was conducted on "Investment Climate and Business Environment Survey in Nigeria".

It was precisely $13^{\text {th }}$ May, 2011, I set out optimistic but worried for the ever congested traffic of Lagos. My task was to locate about a hundred registered members of NASSI (National Association of Small Scale Industrialist) operating in Lagos, Africa most populous city. These small businesses were all registered business owners of at least two to ten years in business operation. They would help complete series of questions arranged in the questionnaire neatly packed in my hand bag. The first contact was an Adhesive and Industrial Gum manufacture of about ten years in business with about 13 employees, locating the factory was not difficult because it is fairly known in the neighborhood. To my surprise the factory was locked, and the surrounding deserted and unkept.It was obvious that production activities has for long ceased. Looking across, was a man standing by the entrance, walked down to ask if he would know if the company has relocated. After scrutinizing me to make sure I'm not working for the federal Inland Revenue or a creditor trying to recover a bad loan, he told me in closed teeth that the company has closed down. I asked him if his business is registered and asked him whether he will like to participate in a research on "Investment Climate and Business Environment Survey in Nigeria". He is a local gin and wine maker - a big industry but sadly he is frustrated by many factors and was planning to leave Nigeria for Europe in search of greener pasture. Another business is about to die. I went straight to the next target, a local brick moulder with locally fabricated molders of various sizes- a medium size business with about 18 employees. The Director also expressed his frustration about the business, also threatening that he may venture into other fast moving consumer goods, blaming high cost of overhead as the killer of business in Nigeria. It down on me that the third business is just some days away from final collapse. I horridly went to the next target, a leather company -producing shoes, bags and belt, to clear my doubt, I checked the address on me with the building number, and my discovery was a total surprise. The leather company is now a restaurant. I asked people around only to be told that the man has left the business and now a taxi driver. All these in a day. The fifth contact was a printing press with six workers, the directors; response was full of frustration and regret. He complained of high energy and raw materials cost. He was using old machine for production.

I continued my survey on business clime in Nigeria and my findings were full of disappointing and discouraging discoveries. I summarized as follows: For every 100 business started ten years ago, only 39 are dead, while 28 in half capacity while on33 are still in operation.

Death of small and large business is on the increase in Nigeria. The sudden death of Dunlop Nigeria, the disappearance of Michelin to Ghana and the total collapse of industry, neglect of agricultural sector further caused death of many small scale enterprises that live on these business firms.

The Corporate Affairs Commission in 2010 delisted over 35,000 business names from the list of active business. It is estimated that two businesses die daily .sadly government don't seem to know how to proffer solution to menace ,worst still, most SMEs operators don't even seem to understand why their business die.

Therefore, the main focus of this paper is to identify the "Reasons why small businesses die in Nigeria "with the aim of proffering a lasting and sustainable solution to the menace.

\section{LITERATURE REVIEW}

According to research, $78 \%$ of businesses failed within the first twelve months, only $22 \%$ make it to ten years. The chief executive officer, Adept Interactive, Mr Aluko Muyiwa says in order to prevent failure; one must know what makes business fail. Small and Medium Enterprises Development Agency (SMEDAN) BOSS ,Alhaji Muhammad Umar said most of the reasons why business failed in Nigeria are not understood by owners and this prevent them from guiding against it. He attributed most of the reasons to the following;

-lack of clear cut concept of the business is the leading factor for the failure.

-poor information about the business and business environment is also identified as a major killer. He said successful entrepreneur must identify and prioritize the 3 major necessities in business development which are: Concept, Capacity and Fund. He stressed that many believe fund is the most important requirement, but said it is the least. 
He emphasized the need for technical competenmce, locaaly relevance and international compliant service providers.

According to SMEDAN, finding has revealed some of the reasons business failed in Nigeria to include: poor management, poor money sense, lack of plan, inexperience and lack of passion and enthusiasm. These factors are business killers. According to the MD, Brian Source International Ltd, Mr. KAMALDEEN Alebiosu says entrepreneur must develop passion and enthusiasm for the business.

Peter with 20 years of experimenting and researching on the reasons why business fail with the aim of helping preventing business failure submit that analysis of reasons for failure suggest that over $60 \%$ of failure is due to poor management practices. Peter concluded that "good management -not fund is the key to business flourishing or dying.

Opinion of analyst and researchers are the same on reasons why business fail in Nigeria.

However, for the purpose of this paper, the following factors have been identified as the reasons for business failure in Nigeria.

\section{TEN MAIN REASON WHY BUSINESSES FAILED IN NIGERIA}

\section{Discounting Training and Experiences}

Most start-up operators go into business with little or no experience about the business. Sadly they talk down undergoing required training assuming the business will run itself because they see others doing the same business and succeeding in it. Some even believe they possess a natural talent or Midas touch, there by discounting the need for proper training and experience. This is a common killer of start-up in Nigeria. A retired banker was paid a good sum of money as retirement benefit, he thought of a business to do, after some consultation decided to venture into fish farming.

He considered it not necessary to undergo needed training before embarking on the project. The project failed in the $9^{\text {th }}$ month. Technical competence and adequate training is the soul of business survival.

\section{Poor Management Practices}

It also observed that most operators don't put in place solid structure that allows steady growth of business. Recruitment, training and welfare system are poor. Business is mostly built around the owner who refuses to separate ownership from the business, but surrounds himself with family and relatives who are not competent. Running of business is a one man show .personnel management; Accounting and book keeping, production, quality control, customer relation and marketing are poorly managed. When the owner dies or retires, 99\% of the business dies almost immediately. A case in question is Concord and Chief M K O Abiola , a renowned business mogul who built his business empire around himself, popular than the companies, failed to separate business from personal life .He was celebrated for his philanthropic life ,but later went into politics, had problem with the military ruler, detained and later killed. The business empire collapsed immediately.

This poor business management automatically prepared the business for investable death. It was observed that $99 \%$ of small businesses don't transit to the $2^{\text {nd }}$ generation because solid management structures are not put in place.

\section{Sloppy Book Keeping and Poor Accounting Practices}

Poor record keeping and accounting practices couple with poor money management is a major killer of SMEs. Most business owners fail to separate profit from revenue while some cannot even differentiate between the two .Gross profits is mostly mistaken for net profit. Some don't really know when business is making profit or loss.

\section{Spending more than reinvesting}

Most start-up owners spend more than reinvest in the business. More money is taken out of business than injected .many take revenue generated as income. This makes it difficult for the new business to expand, take opportunities or survive a misfortune. Most inexperienced owners see revenue generated as income to self and not as fund that need to be reinvested or kept in reserve in case of opportunity or misfortune.

\section{Lack of Adequate Plan}

Lack of strategic planning to enable business achieve its purposes is a major setback to SMEs. Many start-up owners just jump into business by commit ting huge capital into a project without a business plan, no vision of what the business is set out to achieve and strategic plan of achieving it. Most operators think fund is the most important thing -forgetting that a business operating without a plan is just waiting to crash. Thus a solid business plan, sales \& marketing plan as well as good customer relation are the soul of business success. 


\section{Poor Marketing Effort}

A successful business owner must be a good sales person, he must be able to market the company and the products or engage the service of a vibrant sales team. Most small business owners go into production without a single plan of how to sell the products. A fish farmer in Lagos suburb raise about 25 , ooo adult fishes with a very weak sales plan. He was force to feed the stock for additional 45 days at extra cost and eventually sold to middle men below market price. Production was seriously threatened as business was gasping for life. A successful business must know how to find and keep happy and loyal customers.

\section{Lack of Passion and Enthusiasm}

Many start-up operators engage in business because others are doing the same business. Many did not discover their natural interest or passion before starting a venture. They do business solely for the purpose of making profit, when profit does not seem to be coming early as anticipated; they get frustrated and branded the business unprofitable. Most people affected by this factor are not committed and patient enough to take the business to profit before quitting.

Lack of passion, enthusiasm and genuine interest is a major killer of small business.

\section{Lack of good information about the business and poor knowledge of the market.}

Lack of good information about the business and poor knowledge of the market is a great setback for business survival. Relevant and useful information are not readily available or not accessible. Poor knowledge of the business environment is grievous. The business environment in Nigeria is very volatile and unstable-most unstable among them: political, religious, social-cultural, industrial etc. relevant information about business and latest development in the global and local scenes are not readily available. A successful business manager must understand the business environment to navigate. Sometimes because of small capital involved, most operators don't seek adequate information about the market before entering.

Most do not better information about the source of raw materials, price and competition; most do not know how the market is being regulated or what affect demand and supply. Supply and distribution of some items is controlled by cartel or associations. These cartels make it difficult for new entrants who are not member to operate. The author of this paper in 2011 ventured into plastic shopping bag distribution and retailing with a capital of about $\mathrm{N} 250$, 000, but closed down the business a year later because of poor information and knowledge of the market (plastic industry) . The cartel threatened to shut down the business, but gave latter when they learn that the owner won't give in. then the manufacturers posed the greatest problem, they refuse to sell and admit new distributors where they already have one. The company had money, but the producer refused to sell insisting the people should buy from the accredited dealers who have already inflated the price to reduce the margin to almost zero, it was also discovered that one out of the items on the shelves was not needed by the customers- the business died less than 12 months. Sometimes the challenges of what product to sell, for whom to sell and where to get the products to sell could be as intimidating as how to raise finance itself. Most start-up operators don't conduct search to learn what the customers need, they assume they the customers; many discovered this truth when it is too late and the result is usually fatal. Most SMEs owners go into business with the sole aim of making money not to serve people- this is a short cut that lead to dead end.

\section{Infrastructural inadequacy/High Cost of Overhead.}

This has been the greatest problem in the underdeveloped economies of the world. In Nigeria basic amenities are lacking, erratic power supply, lack of portable water, bad roads, corruption, insecurity, civil unrest illiteracy, inter tribal rivalry, vanderlization of public properties, kidnapping, poor access to market and relevant information are the evil confronting business operators in Nigeria. It is extremely difficult for SMEs to thrive in the midst of these hostilities.

These problems have sent many out of operation within the first 12 months.

It is a known fact that the cost of producing ordinary tooth pick in Nigeria is higher than the cost of importing it from Asia (Malaysia) due to high cost of capital and energy.

Nigeria the most populous African country of a population of about 160 million people still live on energy supply of less than 3000 megawatt. The economy is powered by diesel generators. The price of diesel and other petroleum products are not affordable.

Poor energy supply and bad to road to access market are major challenges beyond the control of small business owners. A local producer of paint products some kilometers outside located started very well and was passionate about the chemical and paint market. (It is a huge market with a lot of opportunities.) the business closed down less than two years due to high cost of energy as production is being powered by diesel generator round the day coupled with bad road to access market-the truck supplying finished products to Lagos had accident three times in two months forcing the business to close shop.

For any economy to develop there must be constant supply of power. Corruption and mismanagement are the two duality of evil that have rendered every government intervention useless. 


\section{Insufficient qualified Labour.}

Most business operation require a specialized skill, where this is lacking or not sufficient,

Production will suffer. Sometimes get qualified and committed employees could be as hard as raising finance. This is more common in industries that required .many SME operators sometimes make use of unqualified labour-this on many occasion counterproductive, which eventually leads to failure.

\section{FIGURES AND TABLES}

Characteristics of SMEs based on study findings

In line with one of the objectives of the study, information was sought with respect to certain characteristics of the SMEs (and their operators), including the educational background of the operators, their training and experience before embarking on the project, the type of business they operate, and the size of the enterprise.

Educational background

All the respondents were asked questions related to their educational background (Table 1)

Table 1 Educational background of SME operators

Level of education Frequency Percentage

\begin{tabular}{|l|l|l|}
\hline Level of Education & Frequency & Percentage \\
\hline Primary & 47 & 39.17 \\
\hline Secondary & 41 & 34.17 \\
\hline Tertiary & 32 & 26.67 \\
\hline TOTAL & $\mathbf{1 2 0}$ & $\mathbf{1 0 0 \%}$ \\
\hline
\end{tabular}

Source: Researchers' Survey Findings, 2012.

SMALL AND MEDIUM-SCALE ENTERPRISES IN NIGERIA

The results show that not much people of the respondents had tertiary education (26.67 percent) while the majority had primary and secondary education (73.34 per cent).

\section{CONCLUSION}

It is a known facts that numerous and endless are the challenges confronting business operation especially in Nigeria. However, it is worthy to note according to this write up that eight out ten reasons why business fail are internal factors within the control of small business owners. Though many SME s operator still argue that the other two external factors such as infrastructural inadequacy/high overhead cost and insufficient qualified labour are far greater than the internal factors. Contrary to this assertion, we state here categorically after series of research, observation and experiment that the internal factors account for $70 \%$ of business failure. Study have shown that even where all the amenities, fund, market and government support and protection are available ,companies still fail. Then one can ask "what is killing business? Niger cat, NigerDock, People's Bank, All State, Bank of the North, Nigeria Airway, Nigeria Railway Corporation, National bank ,Wema Bank, Oshogbo Steel Rolling ,Mills, Ajaokuta Power and Steel, Bendel Insurance, Volkswagen Nigeria, Transcorp, Oodua Investment, Federal Palace Hotel, Amusement Park, Nitel, Tran International Bank, Owena Bank, trade Bank- to mention but a few are all public owned corporations owned ,controlled and funded by the government. These corporation enjoy government protection, monopoly of the market and regular funding-but they still died or dying or at least gasping for life.

This fact only reinforces the assertion that internal factors kill business three times faster than external factors. None of the above named public owned corporation died of infrastructural insufficiency or turbulent business environment, but all died of mismanagement and technical incompetence. This paper does not however undermine the problems posed by external factors such as amenities problems. This still remain a huge challenge in under developed and developing economies of the world like Nigeria. We argue that since this is a huge problem, it should also be a huge opportunity. Nigeria with the one of the world fastest growing population of about 160 million, will require technological, industrial as well as improved agricultural and health system to support her ever increasing population. Cheap and affordable items like diapers, biscuits, milk, clothing materials, infrastructural development, such as power, portable water affordable medical care, education, home appliances, automobile, smart phone, food item will be needed by the populace. Meeting this huge need is a promising opportunity.

\section{Acknowledgements}

We are grateful to Almighty God who is our Alpha and Omega for granting us the grace to complete this research work and our lovely families.

Special thank goes to our indefatigable mentors and role models

Our appreciation and unending thanks goes to our role model, Dr. Jimoh Ibrahim (OFR), and also to Engineer 
Alfred O. Dairo and Mr Steve Ayorinde for their constant moral support

Our colleague at Global Fleet Group of companies, LASU and friends at PhD class are also appreciated for their constant constructive academic criticisms that serve as our strength today.

\section{Journal Papers:}

\section{REFERENCES}

[1] Aremu, M. A. (2004). Small Scale Enterprises: Panacea to poverty problem in Nigeria, Journal of Enterprises Development, International Research and Development Institute, Uyo, Akwa Ibom, Nigeria.pg (1-5)

[2] Acharya, S.N. (1981) "Perspectives and problems of development in Sub- Saharan Africa", World Development, 9

[3] Aftab, K. and E. Rahim (1989) "Barriers to the growth of informal sector firms: a case study", Journal of Development Studies, 25(4).

[4] Akamiokhor, G.A. (1983) "Financing small-scale enterprises", Central Bank of Nigeria Bulletin, 8(2). Box, R. de la (1983) "Policies for financing of small-scale industries: Kenyan experience", in N. Molenaar, M.S. El-Namaki and M.P. Van Dijk (eds) Small-Scale Industries Promotion in Developing Countries, The Netherlands.

[5] Chenery, H. et al. (1974) Redistribution with Growth, Oxford: Oxford University Press.

[6] Daniel, P., R.H. Green and M. Lipton (1985) "A strategy for the rural poor", Journal of Development Planning, 15, New York: United Nations.

[7] Ekpenyong, D.B. (1982) "Problems of small businesses and why they fail", Journal of General Studies, Bayero University, Jos, 3(1). International Labour Organization (1973) "Sharing in development: a programme of employment, equity and growth in the Philippines", Geneva: ILO.

[8] Kilby, P. (1969) Industrialization in an Open Economy: Nigeria 1945-66, Cambridge, Cambridge University Press. (1975) "Manufacturing in colonial Africa", in Colonialism in Africa 1969- 78, Vol. 4, London: Cambridge University Press.

[9] Miller, L. (1977) Agricultural Credit and Finance in Africa, New York: Rockefeller Foundation.

[10] Ojo, A.T. (1976) The Nigerian Financial System, Ibadan. (1984) Banking in Nigeria, Graham Burn.

[11] Olofin, S. (1990) "The prospects for an outward-looking industrialization strategy under adjustment in Sub-Saharan Africa", a paper presented at the World Bank Africa Economic Issues Conference, held in Nairobi, 4-7 June.

[12] Oshima, H.T. 91962) "A strategy for Asian development", Economic Development and Cultural Change, 10(3).

\section{Books:}

[2] Andrew Ross Sorkin. The International Best Seller: Too Big To Fail. Pg 3 